Kulyk M.,
Kirchu F.,
Hanesh H.

\title{
THE NUMERICAL CFD INVESTIGATION OF HUB LOSSES OF PUSHING AIR PROPELLERS WITH TANDEM JOINED BLADES OF SMALL SIZED UNMANNED AERIAL VEHICLES
}

\begin{abstract}
Об’єктом дослідження є штовхаючий тандемний гвинт з об’єднаними лопатями. При аналізі характеристик штовхаючих гвинтів виявлено, що одним з проблемних місць є зниження їх ефективності у зв'язку зі зменшенням осьової тяги, що відбувається через утворення зони зниженого тиску (розрідження) в області втулки та кока гвинта. Для штовхаючих гвинтів класичної схеми зниження ефективності сягає рівня 1-2\%. Зазначено, що відносно тандемних гвинтів така інформачія відсутня у зв'язку з тим, що такі конструкцї практично не застосуовуються на літальних апаратах. Однак в останні роки їх потениійні можливості та переваги перед класичними гвинтами підвищили інтерес дослідників до питань застосування тандемних гвинтів на літальних апаратах. Відзначено, що тандемний гвинт повинен мати більші втулкові втрати в порівнянні з класичним гвинтом, оскільки дифузорність міжлопаткового каналу більше. Для очінки значення та встановлення факторів, які впливають на утворення втулкових втрат тандемних гвинтів, проведені дослідження методами чисельної газодинаміки. Для моделювання роботи тандемного гвинта використовувався програмний комплекс ANSYS CFX, в якому реалізований алгоритм вирішення нестаціонарних осереднених по Рейнольдсу рівнянь Нав'є-Стокса замкнутих моделлю турбулентності SST Ментера. В результаті моделювання встановлено, що на рівень вторинних втрат у втулковій частині дворядного гвинта істотно впливає взаємне розташування профілів першої та другої лопаті. При збільшенні кута установки профілів лопаті другого ряду, збільшується розрідження у втулковій частині та в зоні кока, що приводить до виникнення зворотньої тяги, яка зменшує тягу гвинта в середньому на 3-4\%. Отримані результати підтвердили припущення, що втулкові втрати тандемних гвинтів на пряму залежать від дифузорності міжлопаткового каналу в кореневій частині лопатей. Врахування результатів дослідження при проектуванні тандемних гвинтів дозволить зменшити втулкові втрати та підвищити ефективність гвинтів в иілому.
\end{abstract}

Ключові слова: повітряний гвинт, вторинні втрати, гвинтовентилятор, втулковий вихор, тандемний профіль, стрічка Мьобіуса, коробчатий гвинт, тандемний гвинт.

\section{Introduction}

In the last three decades the unmanned aerial vehicles (UAVs) popularity has been growing at an unprecedented rate. Such tendencies are, first of all, related to a significant reduction in the size and cost of electronic devices (processors, sensors, batteries, etc.). Today, the fastest development is taking place in the class of small-sized UAVs, which develops more than 1000 models in more than 50 countries.

As a rule, small push propellers are used as the propulsor in small-sized UAVs whose operational and mass-dimensional characteristics directly influence the efficiency of the aircraft.

The use of pushing propellers for UAVs is usually due to two tasks. The first is the «clean» bow of the aircraft to ensure normal operating conditions of the air navigation and reconnaissance equipment, and the second is the reduction of the aerodynamic drag of the UAV by absorbing the boundary layer which descends. Similar trends are observed in passenger aviation [1, 2]. For example, in order to reduce fuel consumption, the European Flightpath 2050 program [3] focuses on the design of a future generation aircraft with an integrated powerplant. However, along with certain advantages associated with reducing the drag of the aircraft, the propellers integrated in the rear of the fuselage work in worse conditions compared to the front propellers (pull), which operate under unperturbed input conditions.

For pushing propellers of small UAVs, the situation is even more complicated because they work at low Reynolds number [4-6] $\left(\operatorname{Re}=10^{4}-10^{5}\right)$. Unlike propellers operating at high Reynolds numbers $\left(R e>10^{6}, \eta=0.8-0.9\right)$, their efficiency has a much lower level $(\eta=0.4-0.6)$ and to them it is impossible to apply a similarity rule when designing. Both the profile and secondary losses affect the efficiency level. The profile depends on the chord and the length of the blades, and the secondary on the tip and hub vortex flows, 
as well as on the boundary layer formed on the fuselage for aircraft with a propeller. Thus, when designing UAV air propellers, it is necessary to solve a number of conflicting problems. On the one hand, to reduce the mass-dimensional characteristics while increasing the aerodynamic load on the blades, and on the other hand to minimize the profile and secondary losses.

One of the known methods of reducing mass-dimensional characteristics and increasing the aerodynamic loading of propellers is the use of tandem row blades. However, along with the known advantages, such propellers have an increased level of secondary losses (increased intensity of tip and hub vortices).

Therefore, research aimed at establishing the causes and factors affecting on the level of hub losses of tandem propeller is relevant. Since only after establishing the reasons it becomes possible to develop methods to increase their effectiveness.

\section{The object of research and its technological audit}

The air flow in the root part of the propeller is subjected to complex physical influences, leading to the formation of a hub vortex [7, 8], which significantly affects the characteristics of the propeller. This effect can be more or less intense. As a rule, the intensity of the hub vortex depends on the angle of attack of the blade in the root part. The larger the angle of attack, the greater the intensity of the hub vortex. Increasing the angle of attack leads to an increase in the angle of flow twisting in the root part and its premature separation from the surface of the blade. In the case of the use of tandem blades mounted on a common hub, an increased gradient of static pressure behind the rotor blades and the interaction of the first row of blades with the second are also added. When propellers are used on planes made according to the pulling pattern, the hub losses in the propeller itself are insignificant; however, losses are manifested when the tip and hub vortices interact with aerodynamic surfaces $[9,10]$. In the case of pushing propellers, losses must be estimated taking into account the flow around the hub and the propeller. The use of tandem blades [11, 12] makes it possible to increase the aerodynamic load on the blade and to reduce either the rotation speed or the diameter of the propeller compared to the rotor of the classical design. However, an increase in aerodynamic loading also leads to an increase in secondary losses [13].

In general, the design of tandem blade propellers has certain advantages over single row and counter-rotating propellers. However, the almost complete lack of information about tandem propellers with both separate and combined blades led to scientific research aimed at studying their aerodynamic characteristics and flow characteristics.

Thus, the object of research in this work is a propeller with tandem joined blades.

The subject of research is the characteristics of a propeller with tandem joined blades, as well as the structure of the root vortex flows generated by its blades.

\section{The aim and objectives of research}

The aim of research is to determine the quantitative and qualitative characteristics of the tandem pushing propeller, taking into account the flow around its hub and spinner.
In general, the work is focused on solving two problems, namely:

1. Conduct a quantitative assessment of the influence of the hub vortex on the propulsion and economic characteristics of the tandem propeller.

2. Analyze the mechanism of formation of the hub vortex and possible ways to reduce its intensity.

\section{Research of existing solutions of the problem}

Among the main results of studies of hub losses of tandem propellers identified in the resources of the world scientific periodicals, the works [11,13] can be singled out. They indicate that the pusher propellers of the tandem circuit have efficiency lower by 3-4\% compared with the pulling propellers. For single-row classical propellers, such a decrease lies in the range of $1-2 \%$ as shown in [14]. However, these works did not consider the causes and factors affecting the decrease in the efficiency of an isolated pushing propeller, but only a statement of the fact was provided and it was shown that the boundary layer of the fuselage of an airplane mainly affects the decrease in the efficiency of pushing propellers. In [15], the effect of diameters and relative position of propellers in the axial direction was analyzed. It is shown that the relative axial arrangement of the propellers of the first and second rows has a significant effect on the efficiency of the tandem propeller. However, the issues of hub losses remained unexplored, since the study considered a pulling tandem propeller and did not take into account the interaction of the hub vortex with the aerodynamic surfaces of the propeller. However, despite this, the zone of reduced pressure and the region of the hub vortex are rather well reflected. It is also shown that the ratio between the diameters of the first and second rows of rotor blades is of considerable importance for the size of the hub vortex. The hub vortex decreases with decreasing diameter of the second row of blades. Similar research results, only for tandem pushing propellers, are given in $[16,17]$. They also showed that the tandem scheme has larger hub losses than the classic single-row one. The authors in their works emphasize the importance and necessity of studying hub losses, but such results are not presented in the works. In [18], the results of studies of the contra rotating tandem propellers are shown, where it is shown that such a scheme makes it possible to completely eliminate the hub vortex and losses due to the untwisting of the hub vortex from the first row of blades in the second row, but this approach is unacceptable for tandem propellers with joined blades since they rotate together with one peripheral velocity. To reduce hub losses, it was proposed in [19, 20] to use active and passive methods for controlling separated flows on the aerodynamic surfaces of the blades. However, for the effective application of such methods, it is necessary to have accurate information about the nature of separated flows and the reasons that caused them, which can only be determined as a result of research. As it is known, one of the most reliable research methods is the experimental method, however, it has one significant drawback - this is the high cost of research. It was shown in [21, 22] that at the initial stage, it is possible and necessary to use numerical gas dynamics methods for conducting preliminary studies. 
In general, it should be noted that all authors note the importance of studies of hub losses of propellers and factors that affect them. It should also be noted that in the analysis of world scientific periodicals only a few scientific studies were identified that directly relate to the hub losses of tandem pushing propellers, regardless of whether they are propellers with joined blades, or separate. However, despite this, it is necessary to study the hub losses of tandem propellers since at the modern level of development of science and technology they have good prospects for use on aircraft, especially for propellers with integrated blades, which have a low level of tip losses and high aerodynamic loading on the blade.

\section{Methods of research}

5.1. The geometric model and configuration of the object of research. For research, a tandem propeller was chosen (Fig. 1), designed at the Department of Aviation Engines of the National Aviation University (Kyiv, Ukraine), for installation on an unmanned aerial vehicle with a take-off weight of $100 \mathrm{~N}$ (such as a flying wing) as a pusher propeller. The profile of the blades BC-10 (10\%). Propeller diameter is $406 \mathrm{~mm}$ (16 in). Propeller hub diameter is $80 \mathrm{~mm}$. The average pitch of the screw on $0.75 \mathrm{R}$ is $18 \mathrm{in}$. Number of blades is 3 . Number of sections is 9 .

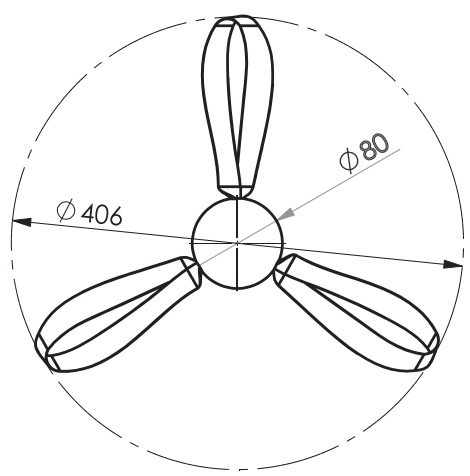

Fig. 1. The basic geometric characteristics of the propeller

The location of the aerodynamic profiles of the propeller blades (Fig. 2), starting from the root section and to $0.8 R$, similar with tandem blade of axial compressors [14].
The characteristics of the propeller were studied at four values of the installation angle of the second row of profiles $\gamma_{2}$, which were calculated according to formula:

$$
\gamma_{2}=\gamma_{1}-\Delta \gamma
$$

where $\gamma_{1}$ is the installation angle of the first row of profiles; $\Delta \gamma$ is the angle between the chords of the first and second profiles.

The installation angle was changed only in the range from the root section to 0.25 of the blade height (Fig. 2, $a$ ).

In the work, $\Delta \gamma$ was taken equal to $0^{\circ},-5^{\circ},-10^{\circ}$, $-15^{\circ}$. When $\Delta \gamma=0^{\circ}$, the chords of the first and second rows are parallel.

The position of the second profile was changed by turning it relative to the point of intersection of the chord and the leading edge.

Thus, the value $\Delta \gamma=-15^{\circ}$ corresponded to an increase in the installation angle of the second profile by $15^{\circ}$.

The operation of the tandem propeller was modeled at a rotation speed of $5000 \mathrm{rpm}$ and free stream flow velocity from 0 to $45 \mathrm{~m} / \mathrm{s}$.

5.2. Numerical method. To simulate stationary, viscous and turbulent flows, let's use the three-dimensional method of numerical gas dynamics, implemented in the software product ANSYS-CFX 15.07. This program solves nonstationary Reynolds averaged Navier-Stokes equations closed by a turbulence model.

The main equations that provide a complete mathematical description of the fluid flow are the equations of conservation:

$$
\text { - mass: }
$$

$$
\frac{\partial \rho}{\partial t}+\frac{\partial}{\partial x_{j}}\left(\rho u_{j}\right)=0
$$

- impulse:

$$
\begin{aligned}
& \frac{\partial}{\partial t}\left(\rho u_{j}\right)+\frac{\partial}{\partial x_{j}}\left(\rho u_{i} u_{j}\right)=-\frac{\partial p^{*}}{\partial x_{i}}+ \\
& +\frac{\partial}{\partial x_{j}}\left(\mu_{e f f}\left(\frac{\partial u_{i}}{\partial x_{j}}+\frac{\partial u_{j}}{\partial i}\right)-\frac{2}{3} \mu_{e f f} \frac{\partial u_{i}}{\partial x_{j}} \delta_{i j}\right)
\end{aligned}
$$

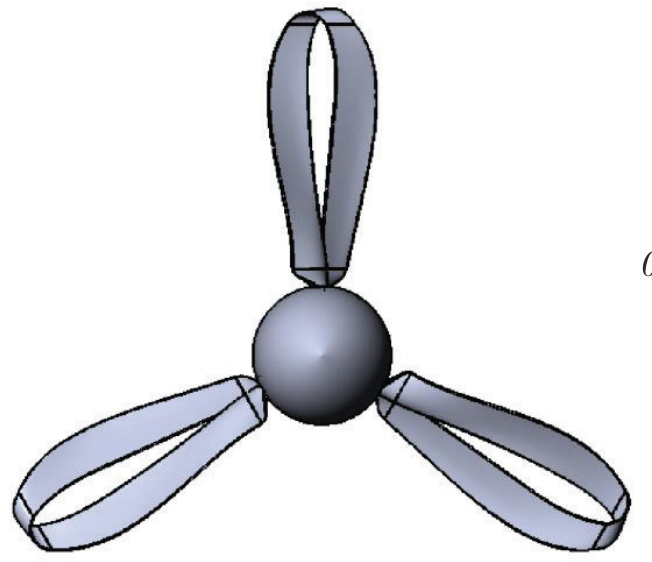

a
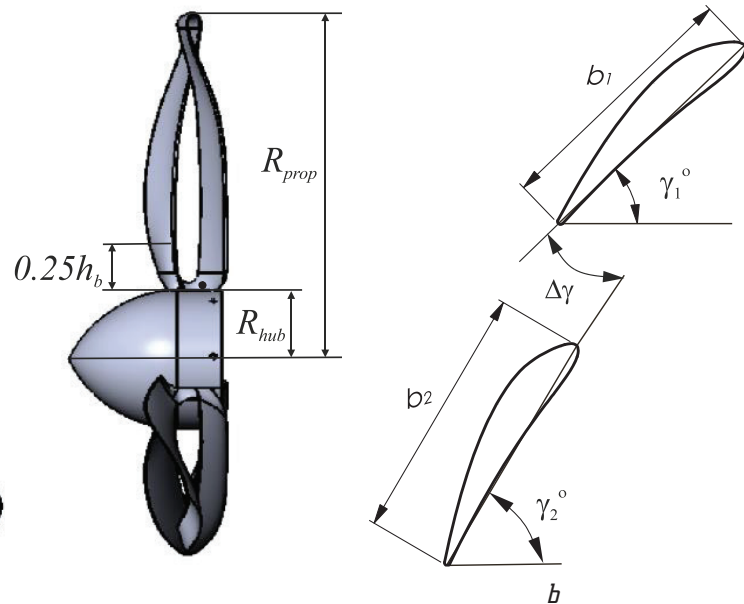

Fig. 2. The geometry of a tandem propeller with joined rotor blades: $a$ - the shape of the propeller; $b$ - the location of the profiles in sections (0.2R-0.8R) along the height of the blade 
- scalar (energy):

$$
\begin{aligned}
& \frac{\partial}{\partial t}(\rho H)+\frac{\partial}{\partial x_{j}}\left(\rho u_{j} H\right)=-\frac{\partial p^{*}}{\partial t}+\frac{\partial}{\partial x_{j}}\left(\lambda \frac{\partial T}{\partial x_{j}}+\frac{\mu_{t}}{\operatorname{Pr}_{i}} \frac{\partial h}{\partial x_{j}}\right)+ \\
& +\frac{\partial}{\partial x_{j}}\left\{u_{i}\left[\mu_{e f f}\left(\frac{\partial u_{i}}{\partial x_{j}}++\frac{\partial u_{j}}{\partial x_{i}}\right)-\frac{2}{3} \mu_{e f f} \frac{\partial u_{k}}{\partial x_{k}} \delta_{i j}\right]+\mu \frac{\partial k}{\partial x_{j}}\right\},
\end{aligned}
$$

where $\mu_{\text {eff }}=\mu+\mu_{t}, \quad p^{*}=p+\frac{2}{3} \rho k$

To close the equations in the work, let's use the model of turbulent viscosity SST [23]. In this model, a smooth transition is organized from the $k-\omega$ model, which well describes shear flows in the near-wall region, to the $k-\varepsilon$ model, which well describes free shear flows. In this case, the kinetic energy transfer equations (5) and the turbulence energy dissipation rates (6) are solved:

$$
\begin{aligned}
& \frac{\partial(\rho k)}{\partial t}+\frac{\partial\left(\rho u_{j} k\right)}{\partial x_{j}}=P-\beta^{*} \rho \omega k+\frac{\partial}{\partial x_{j}}\left[\left(\mu+\sigma_{k} \mu_{t}\right) \frac{\partial k}{\partial x_{j}}\right], \\
& \frac{\partial(\rho \omega)}{\partial t}+\frac{\partial\left(\rho u_{j} \omega\right)}{\partial x_{j}}=\frac{\gamma}{V_{t}} P-\beta \rho \omega^{2}+\frac{\partial}{\partial x_{i}}\left[\left(\mu+\sigma_{\omega} \mu_{t}\right) \frac{\partial \omega}{\partial x_{j}}\right]+ \\
& +2\left(1-F_{1}\right) \frac{\rho \sigma_{\omega 2}}{\omega} \frac{\partial k}{\partial x_{j}} \frac{\partial \omega}{\partial x_{j}},
\end{aligned}
$$

where

$$
\begin{aligned}
P & =\tau_{i j} \tau \frac{\partial u_{i}}{\partial x_{j}}, \tau_{i j}=\mu_{t}\left(2 S_{i j}-\frac{2}{3}\right), \\
\tau_{i j} & =\mu_{t}\left(2 S_{i j}-\frac{2}{3} \frac{\partial u_{k}}{\partial x_{k}} \delta_{i j}\right)-\frac{2}{3} \rho k \delta_{i j}, \\
S_{i j} & =\frac{1}{2}\left(\frac{\partial u_{i}}{\partial x_{j}}+\frac{\partial u_{j}}{\partial x_{i}}\right)
\end{aligned}
$$

Turbulent viscosity is calculated by the formula:

$$
\mu_{t}=\frac{\rho a_{1} k}{\max \left(a_{1} \omega, \Omega F_{2}\right)} .
$$

To determine the turbulent viscosity, the mixing function is used:

$$
\begin{aligned}
& F_{2}=\tanh \left(a_{2}^{2}\right), \\
& a_{2}=\max \left(2 \frac{\sqrt{k}}{\beta^{*} \omega d}, \frac{500 \mathrm{v}}{d^{2} \omega}\right) .
\end{aligned}
$$

To switch between models of turbulent viscosity, the mixing function (8) is used, which takes a value of 1 near the wall and 0 outside the boundary layer, as a result of this, the $k-\omega$ model works near the wall, and $k-\varepsilon$ in all other places.

$$
\begin{aligned}
& F_{1}=\tanh \left(a_{1}^{4}\right), \\
& a_{1}=\min \left[\max \left(\frac{\sqrt{k}}{\beta^{*} \omega d}, \frac{500 v}{d^{2} \omega}\right), \frac{4 \rho \sigma_{\omega 2} k}{C D_{k \omega} d^{2}}\right],
\end{aligned}
$$

where

$$
C D_{k \omega}=\max \left(2 \rho \sigma_{\omega 2} \frac{1}{\omega} \frac{\partial k}{\partial x_{j}} \frac{\partial \omega}{\partial x_{j}}, 10^{-10}\right) ;
$$

$\rho$ - density; $v_{t}=\mu_{t} / \rho$ - kinematic viscosity; $\mu$ - molecular dynamic viscosity; $d$-distance to the nearest wall.

The constants of the turbulent viscosity model are conventionally divided into two types; regular constants and the second type is a linear combination of constants for the $k-\omega$ and $k-\varepsilon$ models. The combination is carried out using the function $F_{1}$ and equation (10). These constants are denoted by index 3 (for example, $\sigma_{k 3}$ ) and are calculated by formula:

$$
C_{3}=F_{1} C_{1}+\left(1-F_{1}\right) C_{2},
$$

where $C_{1}-$ constants of model $k-\omega ; C_{2}-$ constants of model $k-\varepsilon$.

The basic constants were used for modeling:

$$
\begin{aligned}
& {\left[\sigma_{k 1}, \sigma_{k 2}, \beta_{1}, \beta_{2}, \beta^{*}, \alpha_{1}, \alpha_{2}, k\right]=}
\end{aligned}
$$

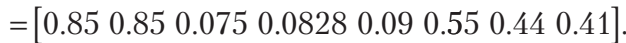

5.3. Calculation area, and boundary conditions. The simulation was carried out in a periodic computational domain (Fig. 3) including two domains: a stationary domain (Stationary domain) with boundary conditions Inlet, Outlet, Opening, Wall and a rotating domain (Rotating domain) with boundary conditions Wall on the surfaces of the blade and the propeller hub. Domains are combined into the computational domain using the «STAGE» mixing interface.

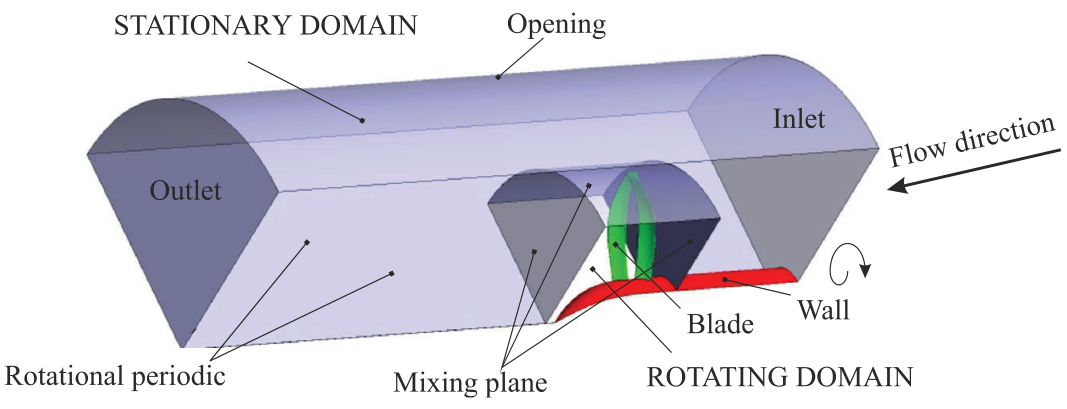

Fig. 3. The topology of the design area of the pushing propeller

The boundary conditions were determined on all surfaces of the calculation model and had the following parameters:

- Inlet - value and direction of the incoming flow velocity, turbulence intensity, static temperature (corresponded to the International Standard Atmosphere at a given height);

- Outlet - static pressure corresponding to ISA at a given height;

- Opening - static pressure for free flow;

- Wall - non-slip adiabatic wall (set on the surfaces of the hub and the blade);

- Rotational periodic - the flow part for one blade was modeled. The opening angle of the domain changed depending on the number of blades and was $180^{\circ}$ for two blades, $120^{\circ}$ for three, and $90^{\circ}$ for four; 
- Stage (mixing plane) - when using a boundary condition of a given type for the mixing plane, the problem in a stationary formulation is solved in each interacting domain. The calculation results of the flow parameters from neighboring domains are transmitted as boundary conditions and spatially averaged (mixed) at the interface of interacting domains. Such mixing eliminates any instability that may arise due to circular irregularities in the flow field (for example, shock waves, vortex flows, etc.), which leads to a steady-state result. Despite the simplifications inherent in the «mixing plane» model, the obtained solutions can provide reasonable approximations of the time-averaged flow field.

5.4. Calculation mesh. For modeling, a block, structured computational mesh was developed with a total number of elements from 3.5 million to 8 million. Most of the elements corresponded to a propeller with two blades, and a smaller one to a propeller with four blades. The computational mesh was separately constructed for the stationary and rotating domains. The design of the topology and the construction of the mesh were carried out in the program ICEM CFD 15.0. The blocks were merged in the ANSYS CFX Pre subprogram. To construct a mesh in the wall regions, the parameter $y^{+}=1.8$, the number of layers within the boundary layer is 20 .

\section{Research results}

To estimate the efficiency of the propeller, used parameters such as: advance ratio $J$; power coefficient $C_{P}$; thrust coefficient $C_{T}$ and coefficient of efficiency $\eta$, which are determined by the formulas:

$$
\begin{aligned}
& J=\frac{V_{\infty}}{n D} ; \\
& C_{P}=\frac{P_{\text {shaft }}}{\rho_{\infty} n^{3} D^{5}} ; \\
& C_{T}=\frac{F_{x}}{\rho_{\infty} n^{2} D^{4}} ; \\
& \eta=\frac{F_{x} V_{\infty}}{P_{\text {shaft }}} .
\end{aligned}
$$

As a result of modeling the tandem propeller, its characteristics were calculated in the operational range of operation at various angles of installation of the second-row profiles in the hub part (Fig. 4, 5).

With an increase the angle of installation of the secondrow profiles, the thrust coefficient remains almost unchanged (Fig. 4, $a$ ), a slight change (within $3-4 \%$ ) is observed in the area with a low free-stream velocity at $J=0-0.2$, which is caused by the flow separation at the root part of the blade. Moreover, the power factor (Fig. 4, $b$ ) changes significantly, and this change occurs in the entire range of operating modes. With an increase in the installation angle of the second row of profiles by $5^{\circ}$, an increase in the power factor by $3 \%$ is observed.

This tendency can be explained by the fact that, on the one hand, an increase in the angle of installation of the second row of profiles leads to an increase in thrust due to an increase in the aerodynamic load of the blade, and on the other hand, the thrust of the propeller decreases due to the formation of rarefaction in the spinner zone of the hub part of the screw (Fig. 4, $d$ ). Thus, thrust compensation occurs. However, with an increase in the angle of installation of the profiles, more energy is required to rotate the propeller, as evidenced by an almost uniform increase in power factor, regardless of the mode of operation of the screw (Fig. 4, b). In turn, an increase in the required power and the absence of an increase in thrust leads to a decrease in the efficiency of the propeller (Fig. 4, c). So with an increase the angle of installation of the second row by $5^{\circ}$, the efficiency decreases on average by $2.5-3 \%$.

The decrease of propeller thrust is due to the presence of a zone of reduced pressure in the spinner area, and depends on the angle of profiles installation in the propeller hub part (Fig. 5). At lower values of the angle of installation, the rarefaction is smaller and, accordingly, the decrease of thrust and loss of total pressure are less (Fig. 5, $a$ ). At large values, the thrust decrease and the total pressure loss are large (Fig. 5, $b$ ).

The presence of a zone of reduced pressure (vacuum) in the rear of the pushing propeller leads to the appearance of a reverse flow and the formation of an intense hub vortex (Fig. 6). 


\section{Pressure}

Pressure
Contour 1
$1.182 e+003$
$8.561 e+002$
$5.298 e+002$
$2.035 e+002$
$-1.227 e+002$
$-4.490 e+002$
$-7.753 e+002$
$-1.102 e+003$
$-1.428 e+003$
$-1.754 e+003$
$-2.080 e+003$
$-2.407 e+003$

$[\mathrm{Pa}]$

Pressure
Contour 1

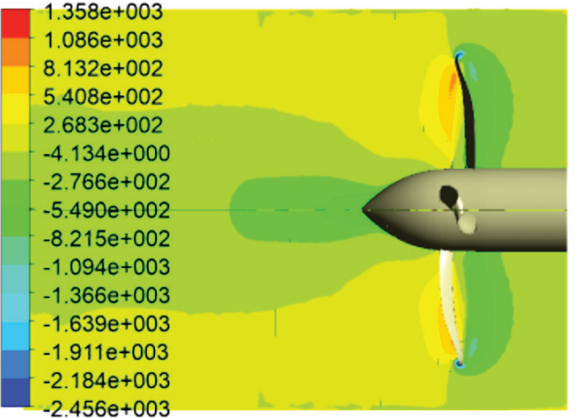

Pa]
Total Pressure in Stn Frame

Contour 1

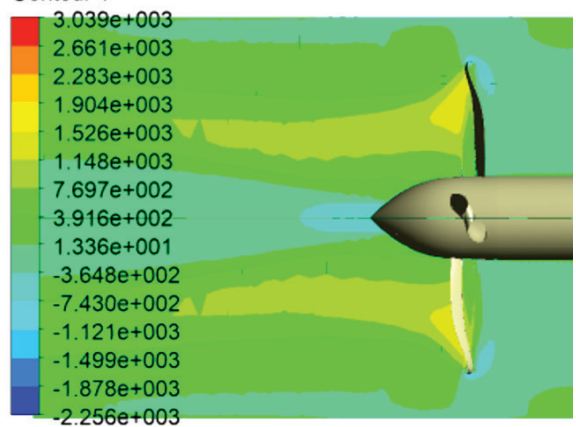

$[\mathrm{Pa}]$

$256 \mathrm{e}+003$

Total Pressure in Stn Frame

$b$

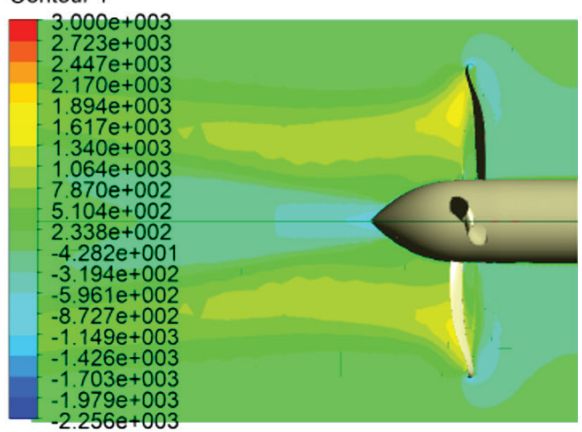

[Pa]

d

second row in the root part of the tandem blade has a significant effect on hub losses. As a result of research, a geometric parameter is determined on which hub losses depend. Such a parameter is the angle between the chords of the first and second row profiles of the tandem blade. Taking this parameter into account and choosing its optimal value when designing tandem propeller can allow increasing propeller efficiency by $2-3 \%$.

Weaknesses. During the research, the influence of the aircraft fuselage on the propeller efficiency was not taken into account.

The boundary layer with the one coming from the fuselage and interacting with the propeller can significantly reduce the effectiveness of the propeller. When designing propellers, this effect should be taken into account, since the fuselage significantly affects the distribution of the axial flow velocity in the area of the propeller hub. Also no experimental studies have been conducted in the work. $b-$ total pressure at $\Delta \gamma=0 ; c-$ static pressure at $\Delta \gamma=10 ; d-$ total pressure at $\Delta \gamma=10$

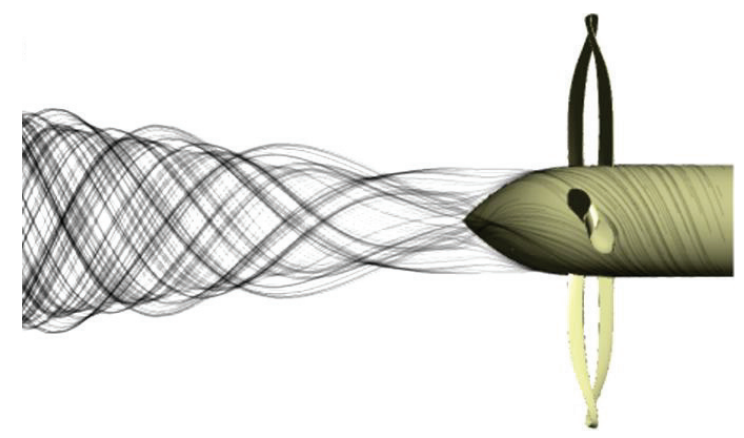

Fig. 6. Hub vortex of tandem push propeller

In shape, the hub vortex resembles a cone. An increase in the installation angle of the second row of profiles leads to an increase in the cone angle and an increase in vacuum in the spinner region.

The main reason for the decrease in efficiency is the negative thrust created by the surface of the propeller hub and spinner, which are in the area of low pressure (vacuum). The vacuum in the rear of the propeller the greater the more the installation angle of blade profiles in the root part. Increasing the angle of installation leads to an increase the tangential component of the flow velocity behind the propeller and a decrease the axial component, thereby intensifying the shear flows between the core and the hub flows, which leads to the twisting of the flow.

\section{SWOT analysis of research results}

Strengths. The studies confirmed the assumption that the mutual arrangement of the profiles of the first and
Opportunities. To increase the efficiency of tandem pusher propeller, it is necessary to apply optimization procedures to determine the location of blade profiles in the hub part. It is also necessary to untwist and increase the moment of air flow in the hub and spinner area of the propeller by using active or passive methods of action. As active methods, this can be blowing or suctioning air from the surface of the hub and propeller spinner. It is also possible to increase the moment of momentum in the hub part by installing additional vortex generators (passive method) behind the propeller blades, which will help to untwist the flow and reduce the vacuum on the propeller spinner.

Threats. To implement the research results, it is necessary to develop a design methodology for pushing tandem propellers taking into account the features of the flow around the root of the blade and also the hub and spinner of propeller.

\section{Conclusions}

As a result of research it was established that:

1. Propulsion and economic characteristics are affected by the installation angle of the second row profiles of the tandem blade. An increase in the installation angle for every 5 degrees with respect to the first row of profiles increases the power factor by $3 \%$, while the efficiency decreases by $2.5-3 \%$. The thrust of the propeller remains practically unchanged, since the drop in thrust on the propeller spinner is compensated by the increase in the aerodynamic loading of the blade in the root part caused by the increase in the installation angle of the profiles of the second row of the tandem blade. 
2. The reason for the formation of the sleeve vortex is the presence of a reduced pressure region behind the screw in the coca region. The rarefaction is affected by the diffusivity of the interscapular canal in the root of the blade. To reduce the intensity of the sleeve vortex, it is necessary to determine the optimal relative position of the profiles in the root of the blade.

\section{References}

1. Atinault, O., Carrier, G., Grenon, R., Verbecke, C., Viscat, P. (2013). Numerical and Experimental Aerodynamic Investigations of Boundary Layer Ingestion for Improving Propulsion Efficiency of Future Air Transport. 31st AIAA Applied Aerodynamics Conference. doi: http://doi.org/10.2514/6.2013-2406

2. Seitz, A., Gologan, C. (2014). Parametric design studies for propulsive fuselage aircraft concepts. CEAS Aeronautical Journal, 6 (1), 69-82. doi: http://doi.org/10.1007/s13272-014-0130-3

3. European Comission. Flightpath 2050: Europe's vision for aviation, report of the high level group on aviation research. (2011). Publications Office of the European Union.

4. Drela, M., Mueller, T. J. (1989). XFOIL - An Analysis and Design System for Low Reynolds Number Airfoils. Low Reynolds Number Aerodynamics. Berlin: Springer-Velag, 1-12. doi: http:// doi.org/10.1007/978-3-642-84010-4_1

5. McGranahan, B. D., Selig, M. S. (2003). Surface Oil Flow Measurements on several Airfoils at Low Reynolds Numbers. 21st AIAA Applied Aerodynamics Conference, Orlando. doi: http:// doi.org/10.2514/6.2003-4067

6. Brandt, J. B. (2005). Small-Scale Propeller Performance at Low Speeds. Champaign. Available at: https://m-selig.ae.illinois.edu/ props/volume-1/Brandt_2005_UIUC-MS-Thesis.pdf

7. Wang, M. H. (1985) Hub Effects in Propeller Design and Analysis. Massachusetts. Available at: https://apps.dtic.mil/ dtic/tr/fulltext/u2/a158853.pdf

8. Yin, J., Stuermer, A., Aversano, M. (2012). Aerodynamic and Aeroacoustic Analysis of Installed Pusher-Propeller Aircraft Configurations. Journal of Aircraft, 49 (5), 1423-1433. doi: http:// doi.org/10.2514/1.c031704

9. Yang, Y., Zhou, T., Sciacchitano, A., Veldhuis, L., Eitelberg, G. (2016). Propeller and inflow vortex interaction: vortex response and impact on the propeller performance. CEAS Aeronautical Journal, 7 (3), 419-428. doi: http://doi.org/10.1007/s13272-016-0198-z

10. Yang, Y., Zhou, T., Sciacchitano, A., Veldhuis, L., Eitelberg, G (2015). Propeller and inflow vortex interaction: vortex response and impact on the propeller performance. 5th CEAS Air \& Space Conference. Delft, Sep.

11. Capitao Patrao, A. (2018). On the Aerodynamic Design of the Boxprop. Gothenburg, 74. Available at: https://www.researchgate. net/publication/328530718_On the Aerodynamic_Design_of the Boxprop

12. Shen, C., Qiang, X., Teng, J. (2012). Numerical and experimental investigation of an axial compressor flow with tandem cascade. Journal of Thermal Science, 21 (6), 500-508. doi: http://doi.org/ 10.1007/s11630-012-0574-x

13. Capitao Patrao, A., Avellán, R., Lundbladh, A., Grönstedt, T. (2016). Wake and Loss Analysis for a Double Bladed Swept
Propeller. Proceedings of ASME Turbo Expo. Seoul. doi: http:// doi.org/10.1115/gt2016-56540

14. Ruchala, P. (2016). An influence of pusher propeller cover on its performance - A concept of wind tunnel investigation. Journal of KONES, 23 (4), 429-434. doi: http://doi.org/ 10.5604/12314005.1217263

15. Xu, J.-H., Song, W.-P., Yang, X.-D., Zhang, Y. (2017). Investigation on Improving Efficiency of High-Altitude Propeller with Tandem Configuration. AIAA AVIATION Forum. 35th AIAA Applied Aerodynamics Conference. Denver, 12. doi: http://doi.org/ 10.2514/6.2017-3575

16. Djihada, B., Omar, I. (2017). Impact of some geometrical aspects on the tandem co-rotating propeller hydrodynamic characteristics. Brodogradnja, 68 (1), 107-123. doi: http://doi.org/ 10.21278/brod68107

17. Jiang, X., Li, T., Hu, J., Lin, Y. (2019). Numerical Simulation and Design of Parameter Matching on the Open Water Performance of CRP. The 29th International Ocean and Polar Engineering Conference. Honolulu, 8.

18. Jung, H., Kanemoto, T., Liu, P. (2017). A Numerical Prediction of Tip Vortices from Tandem Propellers in the Counter-Rotating Type Tidal Stream Power Unit. Journal of Power and Energy Engineering, 5 (12), 66-74. doi:10.4236/jpee.2017.512009

19. Tillman, G., Ochs, S. S., Kearney, J. S., Wake, B. E. (2006). Control of high-reynolds-number turbulent boundary layer separation using counter-flow fluid injection. 3rd AIAA Flowe Control Conference, 14. doi: http://doi.org/10.2514/6.2006-3025

20. Cerretelli, C., Gharaibah, E., Toplack, G., Gupta, A., Wuerz, W. (2009). Unsteady separation control for wind turbine applications at full scale reynolds numbers. 47th AIAA Aerospace Sciences Meeting, 13. doi: http://doi.org/10.2514/6.2009-380

21. Parra P. H. G., Angulo M. V. D., Gaona G. E. E. (2018). CFD Analysis of two and four blades for multirotor Unmanned Aerial Vehicle. Conference: 2018 IEEE 2nd Colombian Conference on Robotics and Automation (CCRA), 7. doi: http://doi.org/ 10.1109/ccra.2018.8588130

22. Shi, W., Li, J., Yang, Z., Zhang, H. (2018). CFD Analysis of Contrarotating Open Rotor Aerodynamic Interactions. International Journal of Aerospace Engineering, 2018, 1-13. doi: http:// doi.org/10.1155/2018/9538787

23. Menter, F. R. (1994). Two-equation eddy-viscosity turbulence models for engineering applications. AIAA Journal, 32 (8) 1598-1605. doi: http://doi.org/10.2514/3.12149

Kulyk Mykola, Doctor of Technical Sciences, Professor, Head of Department of Aviation Engines, National Aviation University, Kyiv, Ukraine, e-mail: aki@nau.edu.ua, ORCID: https://orcid.org/00000003-2149-4006

Kirchu Fedir, PhD, Associated Professor, Department of Aviation Engines, National Aviation University, Kyiv, Ukraine, e-mail: fkirchu@gmail.com, ORCID: https://orcid.org/0000-0001-8437-4402

Hanesh Hussein, Postgraduate Student, Department of Aviation Engines, National Aviation University, Kyiv, Ukraine, e-mail: husseinalamy1970@gmail.com, ORCID: https://orcid.org/00000002-8995-7866 